\title{
EFFECT OF USING BEE BREAD EXTRACT AS FEED ADDITIVES ON DIGESTIBILITY AND PRODUCTIVE PERFORMANCE OF MATERNAL GOATS DURING SUCKLING PERIOD.

\author{
Mona E. Farag ${ }^{*}$; Azza A. Helmy ${ }^{2}$ and Amal M.M.El-Nimer ${ }^{3}$
} \\ ${ }^{1}$ Department of Animal Nutrition Res., ${ }^{2}$ Department of Buffalo Research and \\ ${ }^{3}$ Department of Dairy Technology Animal Production Research Institute (APRI), Agricultural Research center (ARC), Dokki, Giza, Egypt. \\ *1-Email - mona.farag@arc.sci.eg
}

Key Words: Maternal goats, daily gain of kids, bee bread extract, suckling milk and productive a performance.

\section{ABSTRACT}

The aim of this study was carried out to investigate the effect of using bee bread extract (BBE) as feed additive on productive a performance as milk yield and its composition of maternal goats during suckling period. As well as the growth performance of suckling kids and immunity status were studied. Eighteen Zaraibi goats averaged postpartum live body weight (LBW) $38.73 \mathrm{~kg}$ and aged 3-4 years as well as a number of born kids (twin) were divided randomly into three similar groups, where each one was allocated on the following dietary treatments. The control ration (T1) consisted of concentrate feed mixture (CFM) $70 \%$ + roughage $30 \%$ were the roughage portion was consisted of $25 \%$ berseem hay $(\mathrm{BH})+5 \%$ rice straw (RS), according to NRC (2007), with $5.0 \mathrm{ml}$ of distilled water / head / daily throughout 90 -d. trial period. While the second and third groups (T2 and T3) were received the same control ration plus orally a dose of BBE 2.5 and $5.0 \mathrm{ml}$ / head / daily throughout the trial period days, respectively. Results showed that the all digestibility coefficients and nutritive value as TDN and DCP for T3 or T2 were significant $(\mathrm{P}<0.05)$ improved as compared with the T1 (control ration). Also, animals received BBE (T3 or T2) recorded higher $(\mathrm{P}<0.05)$ average changes of body weight, BCS of maternal goats and enhance $(\mathrm{P}<0.05)$ fed conversion and daily gain of their kids, milk yield and its components, classification of immunoglobulins in suckling milk, some blood serum parameters and economic efficiency than those the control ration (T1). However, differences were not significant $(\mathrm{P}>0.05)$ for both $\mathrm{T} 3$ and $\mathrm{T} 2$ among them. The present study indicate that the animals fed BBE as fed additives (T3 or T2) at concentrations of 2.5 and $5.0 \mathrm{ml} /$ daily during critical period of suckling months could be caused positively effect on productive performance, suckling milk yield and it quality which reflected on health and growth rate of kids. 


\section{INTRODUCTION}

Today, the use of products of natural origin must have a perspective program of development Livestock to reach the specified aims of its implementation. Bee bread refers to the pollen collected by bee, added with nectar and bee salivary enzymes and stored inside a bee hive where it undergoes lactic acid fermentation (Mohammad et al., 2020). The bee products are including the honey, pollen, extracts derived from bee bread, propolis, royal jelly and bee venom. Bee products demonstrate a wide range of healing effects (Al-Salem et al., 2016). Meanwhile, Habryka $\boldsymbol{e t}$ al., (2016) defined that these products increase the level of ATP, neutralize effect on many toxic agents, increase immunity, improve the energy balance of tissues and protein metabolism, involved in the synthesis of nucleic acids and essential to the proper functioning of the circulatory system of living organisms. In addition, bee products as dietary supplements rich in vitamins and minerals than that of artificially mineral-vitamin profile (Madras-Majewska et al., 2015) and have access as well as significantly affect the productive performance and animal's health. Consequently, mainly the bee products such as the bee bread (fermented of bee pollen) has been characterized by a wide range of biological properties (Asama et al., 2015). Furthermore, Zuluaga $\boldsymbol{e t}$ al., (2015) found that the bee bread mainly includes pollen, honey secretions of bees' salivary glands and also it has characterized by a higher nutritional value, better digestibility and richer in chemical composition than pollen. According to the other sources, Habryka et al., 2016 revaluated that bee bread contains considerably larger amounts of peptides, free amino acids and presence all essential amino acids. They also added that bee bread to get over of deficiency of vitamins B (very helpful in the nerves activation) and $\mathrm{K}$ (prevention the poor condition of the blood vessels) and played a huge role in detoxification process stimulation. Findings of, De-Melo and de Almeida-Muradian (2017) who administered that bee breed extract did not change the $\mathrm{pH}$ of ruminal fluid, significantly change the total amount of short-chain fatty acids (acetic acid and propionic acid, their ratio), the total number of protozoa while could be improve the digestibility of dry matter and causing a significant decrease in ruminal gases especially ammonia and methane. In addition to these potential benefits, Mărgăoan et al., 2019 noticed that bee bread could improve immunity, as well as micro- and macroelements for metabolic processes. It potentially can be considered as a high-quality fed additives because of its balanced content of proteins, carbohydrates and fats. 
Generally, bee bread has antioxidant activity due to the presence of $\alpha$-tocopherol and phenolic compounds as well as working as an antimicrobial against some pathogenic bacteria (Pseudomonas aeruginosa, Salmonella enterica, Staphylococcus aureus, Escherichia coli and Bacillus cereus) and in the meantime took place as an antitumor role against different tumor cell lines, antihypertensive activity and neuroprotective activity (Dranca $\boldsymbol{e t}$ al., 2020).

Although, researches have focused on using of bee products mainly in livestock, but there are no previous reports dealing with BBE as welfare of kids during suckling period. Therefore, this study has demonstrated its potential dosage for maternal Zaraibi goats by BBE to improve digestibility and feeding values, productive and reproductive performance, suckling milk yield and quality as well as on growth rate and health of kids.

\section{MATERIALS AND METHODS \\ Location and date of experiment}

This study was conducted at El-Serw Research Station Animal Production Research Institute, Agriculture Research Center, Damietta governorate, Egypt. The experimental period was extended from first of November 2020 up to weaning in first of March 2021.

\section{Extraction procedure of bee bread}

Distilled water was used as a solvent to prepare the aqueous of bee bread extract (BBE). About 10g of BBE was suspended and extracted by shaking with $100 \mathrm{ml}$ of distilled water at $20^{\circ} \mathrm{C}$ for 1 day and the solution was centrifuged at $5000 \mathrm{rpm}$ for one hour. The supernatants were collected and BBE extract filled. Then, the extract was stored in desiccators until use for further studies. Table (1) is showed that the chemical analysis of BBE extract according to Bakour et al. (2017) and Ismail et al. (2018).

Table (1) : Chemical analysis of the bee bread.

\begin{tabular}{|c|c|c|c|c|c|c|c|c|c|c|}
\hline \multirow[t]{2}{*}{ Item } & \multicolumn{7}{|c|}{ Chemical composition ( $\%$ on dry matter basis) } & \multirow{2}{*}{$\begin{array}{r}* * \text { Tot } \\
\text { tioxidant }\end{array}$} & \multirow{2}{*}{$\begin{array}{l}\text { henol } \\
\text { mg }\end{array}$} & \multirow{2}{*}{$\begin{array}{l}\text { Ash } \\
1100\end{array}$} \\
\hline & DM & $\mathbf{O M}$ & CP & EE & CF & NFE & Ash & & & \\
\hline *BBE & 90.15 & 97.48 & 19.40 & 8.19 & 6.30 & & 2.52 & 143.78 & 4.88 & 1.70 \\
\hline
\end{tabular}

* BBE: bee bread extract

** As ascorbic acid equivalents/g.

\section{Experimental animals and feeding trail}

The present study was carried out using eighteen Zaraibi goats averaged post-partum live body weight (LBW) $38.73 \mathrm{~kg}$ and aged 3-4 years as well as in the number of birth kids (twin) were divided randomly into three similar groups, where they were allocated into three dietary treatments. 
The control ration (T1) consisted of concentrate feed mixture (CFM) $70 \%+$ roughage $30 \%$, roughage portion consisted of $25 \%$ berseem hay $(\mathrm{BH})+5 \%$ rice straw (RS). Wherein the nutritional requirements for accounted according to NRC (2007), with $5.0 \mathrm{ml}$ of distilled water / head / daily, whereas the second and third groups as tested ones (T2 and T3) received the same control ration plus orally a dose of BBE at 2.5 and $5.0 \mathrm{ml} /$ head / daily, respectively. Feeding requirements were adjusted biweekly according to weight changes and milk production. The experiment has continues over the first ninety days after birth. Water and salt blocks were available at all times. Roughage (BH and RS) was offered twice daily at 7 a.m. and 3 p.m., while the daily required CFM was offered at 9 a.m. and 4 p.m. in equal a mounts. Maternal goats and kids were weighed post-partum (initial weight) and then periodically every two weeks before morning feeding over a 90-d experimental period and recorded regularly. Throughout the feeding period, scales of body condition scoring (BCS) of maternal goats was monthly recorded for each animal according to Saddick and Ahmed (1991). The above mentioned measurements were made on all goats at the same weighing times. Measurements as well as weighing took place in the morning after overnights holding of feed and water. Chemical composition of $\mathrm{CFM}, \mathrm{BH}, \mathrm{RS}$ and basis experimental ration were analyzed according to AOAC (2007) and are presented in Table (2).

Table (2) : Chemical composition of CFM, BH and RS.

\begin{tabular}{|r|r|r|r|r|r|r|r|}
\hline \multirow{2}{*}{ Items } & \multicolumn{7}{|c|}{ Chemical composition (\% on dry matter basis) } \\
\cline { 2 - 8 } & DM & OM & CP & EE & CF & NFE & Ash \\
\hline *CFM & $\mathbf{8 9 . 9 1}$ & $\mathbf{8 7 . 7 7}$ & $\mathbf{1 4 . 4 0}$ & $\mathbf{2 . 4 1}$ & $\mathbf{1 2 . 0 9}$ & $\mathbf{5 8 . 8 7}$ & $\mathbf{1 2 . 2 3}$ \\
\hline BH & $\mathbf{8 8 . 6 5}$ & $\mathbf{8 8 . 4 3}$ & $\mathbf{1 2 . 1 2}$ & $\mathbf{2 . 1 5}$ & $\mathbf{2 3 . 2 9}$ & $\mathbf{5 0 . 8 7}$ & $\mathbf{1 1 . 5 7}$ \\
\hline RS & $\mathbf{9 2 . 8 3}$ & $\mathbf{8 0 . 2 3}$ & $\mathbf{3 . 0 8}$ & $\mathbf{1 . 4 9}$ & $\mathbf{3 6 . 8 8}$ & $\mathbf{3 8 . 7 8}$ & $\mathbf{1 9 . 7 7}$ \\
\hline R & $\mathbf{8 9 . 7 4}$ & $\mathbf{8 7 . 5 1}$ & $\mathbf{1 3 . 2 6}$ & $\mathbf{2 . 3 0}$ & $\mathbf{1 6 . 1 3}$ & $\mathbf{5 5 . 8 7}$ & $\mathbf{1 2 . 4 4}$ \\
\hline
\end{tabular}

* The CFM consisted of $26 \%$ undecortecatedicotton meal, $40 \%$ yellow corn, $27 \%$ wheat bran, $3.5 \%$ molasses, $2 \%$ limestone, $1 \%$ common isalt and $0.5 \%$ minerals imixture.

\section{Digestibility trials:}

Nine mature bucks average live body weight of $37.43 \pm 1.21$ was used to conduct three digestibility trials to determine the digestibility and feeding values of the experimental rations. Bucks were divided into three groups ( 3 animals each) accustomed to stand in metabolic cages as well as used to experimental diets for two weeks as preliminary periods followed by one week as collection period. Every group was fed on of the previous rations mentioned before for feeding trial. Rations were offered twice daily at 9 a.m. and 4 p.m. to the animals and clean drinking water was available. During the collection periods, feed intake and leftover were measured, representative samples were collected. Each 24- 
hr faces were quantity collected and aliquot samples were kept for chemical analysis.

\section{Milk yield and composition}

The quantities of suckling milk in different treatments were evaluated at early (5, 15 and 30 days), middle (60 days) and late (90 days) by the following protocol of Khalifa et al., (2013). This protocol was used the oxytocin method as injecting double doses ( $2 \mathrm{IU} /$ maternal goat) of oxytocin intravenously after kids were separated. The first oxytocin dose was injected, after two minutes the udder milk emptied by handly and this amount of milk discarded. After 4 hours of elapse kids' separation the second oxytocin dose was injected. Then, the udder milking handily and this amount of milk discarded also, this amount of milk was recorded. The suckling milk amount was calculated using the following equation= suckling milk amount $(\mathrm{g})$ obtained in 4 hours (as the isolation time of kids from their maternal) $\times 6$ (as a factor) give the amount of milk was suckled during 24 hours.

The composition of suckling milk from post-partum to weaning were analysed during suckling period using $50 \mathrm{ml}$ of milk /goat. Then, the composition of suckling milk included fat\%, protein $\%$, lactose \% (using digital Lactoscans, Milk analyzer, Wide LCD 8900 Nova Zagora, Bulgaria) and suckling milk energy $(\mathrm{kcal} / \mathrm{kg}$ ) calculated using this equation: $203.8+$ $(8.36 \times f a t \%)+(6.29 \times$ protein \%) according to Khalifa et al., (2016) . While, $\operatorname{IgA}, \operatorname{IgG}$ and $\mathrm{IgM}$ concentrations were determined using reagent kits as ELISA kits (Bethyl Laboratories, Montgomery, TX, USA), and the procedures were followed according to manufacturer's instructions.

\section{Biochemical constituents of blood of goats}

Fifteen maternal goats ( $\mathrm{N}=5$ / treatment) were randomly chosen to collect blood samples at weaning where about $10 \mathrm{ml}$ of blood samples were collected from the jugular vein of each animal into clean tubes. Then, the serum samples were obtained by centrifugation for $30 \mathrm{~min}$ at $3000 \mathrm{rpm}$ and stored at $-18{ }^{\circ} \mathrm{C}$ until the analysis. Samples were analysed for total protein, albumin, globulin, glucose, cholesterol, low density lipoprotein (LDL), high density lipoprotein (HDL), total lipids, urea, creatinine and the activities of aspartate amino-transferase (AST) and alanine amino-transferase (ALT). The determination was assayed by commercial kits produced by BioMerieux (Craponne, France).

\section{Statistical Analysis}

Statistical evaluation of significant difference between means (mean \pm SEM) were performed by ANOVA followed by the Duncan post hoc test to determine significant differences in all the parameters among all energy addition types using the SAS computer program (SAS)

Statistics version 2002). The significance differences between means were calculated using Duncan's Multiple Range test (1955). 


\section{RESULTS AND DISCUSSION}

\section{Changes of LBW and BCS of maternal goats during suckling period}

The results of maternal goat's performance are showed in Table (3). The LBW of maternal goats during suckling period were almost similar among the different experimental rations at different interval of this period, while, the body weight chances and BCS of goats fed the two tested rations ( 22 andT3) were improved significantly $(\mathrm{P}<0.05)$ in relation to those of control one (T1), being the superior values were occurred with T3 at the differ periods. It is noteworthy noting that a significant decrease in both live body weight and BCS of goats were observed immediately after birth until 30-d of suckling phase in the different groups of experiment. Then such values gradually increase $(\mathrm{P}<0.05)$ during the rest of trial periods, being significant higher rate in the animals received $\mathrm{BBE}$ (T3or T2) rations compared with the control group. This might be due to the favorably modify the ruminal environment by caused a low of ruminal ammonia and methanol that reflected positively on improve body weight and animal health (De-Melo and de Almeida-Muradian., 2017). While, Urcan et al., (2017) found that bee bread is the best source of tyrosine that played an important role to synthesize thyroid hormones which affected on metabolic functions that in turn affected on improved productive performance of animals. Also, the previous authors confirmed that thyroid hormones could be increased the basal metabolic rate of carbohydrate, lipids and proteins which may have been responsible for alleviative or preventive weight loss and even increased it. As well, the amelioration of LBW in the current study may be attributed to more nutritional substances like antioxidant, vitamins and minerals in bee bread which located in either $\mathrm{T} 2$ or $\mathrm{T} 3$ treatments compared that of free one in $\mathrm{T} 1$ group. These results are in line with the findings of Hudz et al., (2017) who stated that it is possible to improve antioxidant status by bee bread as natural antioxidants. Generally, the increased level of antioxidants and vitamins in feedstuffs could be considered as one of the most important ways to prevent less weight (Mărgăoan et al., 2019). In addition, Bleha et al., (2019) reported that the presence of antioxidant properties in bee bread has powerful nutritional value, could remove free radicals in the blood stream, and regarded as a well-balanced diet necessary for health. On the other hands, Ribeiro et al., (2018) found that minerals (macrominerals and microminerals) could be played a main role to improve body weight, essential to metabolic processes and the deficiency can result in disturbances, cause impair animals performance, retard growth and reduce the digestibility of diet. 
Table (3): Changes of LBW and BCS in maternal goats fed different dietary treatments during suckling period.

\begin{tabular}{|c|c|c|c|c|}
\hline \multirow[t]{2}{*}{ Specification } & \multirow{2}{*}{$\begin{array}{l}\text { Suckling period } \\
\text { days }\end{array}$} & \multicolumn{3}{|c|}{ Experimental treatments } \\
\hline & & T1 & T2 & T3 \\
\hline \multirow{6}{*}{ LBW, kg } & Post-partum & $38.92 \pm 0.47$ & $38.50 \pm 0.58$ & $38.77 \pm 0.41$ \\
\hline & At 7 days & $38.51 \pm 0.50$ & $38.16 \pm 0.61$ & $38.50 \pm 0.44$ \\
\hline & At 15 days & $38.16 \pm 0.49$ & $37.96 \pm 0.61$ & $38.35 \pm 0.45$ \\
\hline & At 30 days & $37.91 \pm 0.51$ & $37.81 \pm 0.60$ & $38.26 \pm 047$ \\
\hline & At 60 days & $38.07 \pm 0.49$ & $38.10 \pm 0.62$ & $38.64 \pm 0.48$ \\
\hline & At 90 days & $38.69 \pm 0.48$ & $38.99 \pm 0.51$ & $39.79 \pm 0.61$ \\
\hline \multirow{5}{*}{ Weight changes g } & Post-partum- 7 d. & $-410^{\mathrm{a}}$ & $-340^{b}$ & $-270^{\mathrm{c}}$ \\
\hline & $7-15 \mathrm{~d}$. & $-350^{a}$ & $-200^{b}$ & $-150^{c}$ \\
\hline & $15-30 \mathrm{~d}$. & $-250^{a}$ & $-150^{b}$ & $-090^{\mathrm{c}}$ \\
\hline & $30-60 \mathrm{~d}$. & $+160^{c}$ & $+290^{b}$ & $+380^{\mathrm{a}}$ \\
\hline & $60-90 \mathrm{~d}$. & $+620^{c}$ & $+890^{b}$ & $+1150^{a}$ \\
\hline \multirow{4}{*}{ BCS, 1- 5 scales } & Post-partum & $2.76 \pm 0.07$ & $2.68 \pm 0.09$ & $2.71 \pm 0.10$ \\
\hline & At 30 days & $2.41 \pm 0.04^{b}$ & $2.47 \pm 0.07^{a}$ & $2.57 \pm 0.08^{a}$ \\
\hline & At 60 days & $2.48 \pm 0.04^{b}$ & $2.59 \pm 0.07^{\mathrm{a}}$ & $2.76 \pm 0.08^{\mathrm{a}}$ \\
\hline & At 90 days & $2.61 \pm 0.05^{b}$ & $2.78 \pm 0.10^{a}$ & $2.97 \pm 0.09^{a}$ \\
\hline
\end{tabular}

a,b,c means in the same row direction with different superscripts are significantly different $(\mathbf{P}<\mathbf{0 . 0 5})$.

\section{Digestibility coefficients and feeding values}

Data of Table (4) cleared that goats fed ration T3 recorded significant higher $(\mathrm{P}<0.05)$ all digestibility values of $\mathrm{DM}, \mathrm{OM}, \mathrm{CP}, \mathrm{CF}$, EE and NFE and also feeding values as TDN and DCP while the values such items were insignificant higher with those fed ration, T2 than those fed control one (T1). This might be due to the fermentation process in the rumen that based on the action of probiotic that excreted by, both bacteria and protozoa. Hence the importance of bee bread supplements due its content from antioxidant, vitamins and minerals could be positively effect on the activity of beneficial microflora in rumen compartments, thus improves the digestibility parameters and feeding values of a diet. These results are in agreement with those reported by Ribeiro et al., (2018) who found that macro and micro-minerals especially potassium, phosphorus, magnesium and zinc could be played a main role to improve the metabolic processes, while its deficiencies cause can disturbances effects and impair animals performance, retard growth and reduce the digestibility of nutrients. Accordingly, Mohammad et al., (2020) found that bee bread is the best source to provide macro and micro-minerals whereas the most abundant mineral in bee bread were potassium $(6524.9$ 
$\mathrm{mg} / \mathrm{kg}$ ) followed by phosphorus $(6402.3 \mathrm{mg} / \mathrm{kg})$ and magnesium $(1635.4$ $\mathrm{mg} / \mathrm{kg}$ ).

Table (4): Digestibility and feeding values of the experimental rations.

\begin{tabular}{|c|c|c|c|c|}
\hline \multirow[b]{2}{*}{ Item } & \multicolumn{4}{|c|}{ Experimental treatments } \\
\hline & T1 & T2 & T3 & SE \\
\hline \multicolumn{5}{|c|}{ Digestibility coefficients } \\
\hline DM & $67.65^{\mathrm{b}}$ & $69.34^{\mathrm{ab}}$ & $71.55^{\mathrm{a}}$ & 0.65 \\
\hline OM & $69.54^{\mathrm{b}}$ & $71.88^{a b}$ & 73.78a & 0.58 \\
\hline $\mathbf{C P}$ & $65,69^{b}$ & $67,80^{a b}$ & $69.23^{\mathrm{a}}$ & 0.34 \\
\hline $\mathbf{C F}$ & $59.24^{\mathrm{b}}$ & $61.65^{\mathrm{ab}}$ & $63.58^{\mathrm{a}}$ & 0.61 \\
\hline EE & $71.47^{\mathrm{b}}$ & $74.39^{\mathrm{ab}}$ & $75.78^{\mathrm{a}}$ & 0.58 \\
\hline NFE & $72.11^{b}$ & $75,84^{a b}$ & $\mathbf{7 6 , 5 4 ^ { \mathrm { a } }}$ & $0.72^{\mathrm{a}}$ \\
\hline \multicolumn{5}{|c|}{ feeding values } \\
\hline TDN & $62.26^{b}$ & $65.15^{\mathrm{ab}}$ & $66.12^{\mathrm{a}}$ & 0.67 \\
\hline DCP & $8.71^{b}$ & $8.99^{\mathrm{ab}}$ & $9.18^{\mathrm{a}}$ & 0.34 \\
\hline
\end{tabular}

a,b,c means in the same row direction with different superscripts are significantly different $(\mathbf{P}<\mathbf{0 . 0 5})$.

\section{Milk yield and composition}

The suckling milk yield was significantly $(\mathrm{P}<0.05)$ higher in goats fed $\mathrm{T} 3$ and $\mathrm{T} 2$ rations than that of control one (T1) as illustrated in Figure (1). Definitely results are cleared that bee bread might be performed as lactogenic substance, because it can increase milk production by scavenging activity of free radical (Bakour et al., 2017), supplied goats with vitamins (Mărgăoan et al., 2019), antioxidant (Bleha et al., 2019), goodness energy and fatty acids (Dranca $\boldsymbol{e t}$ al., 2020) and organic acids (Mohammad et al., 2020). Also, significant improvement in suckling milk yield perhaps attributed to the variation in the minerals level in bee bread extracts in the dietry treatments (T3 and T2) especially zinc which has positive effect on production of milk in comparison with $\mathrm{T} 1$ ration. Such results are an agreement with those the findings by Sprinkle $\boldsymbol{e t}$ al., (2018) who found that obtained zinc plays an important role in the proper function of the first mechanism of milk production and it also affects the degree of keratinization of the teat canal, thereby protecting the udder against bacterial penetration after milking. More recently, a related study clearly demonstrated that deficiency of $\mathrm{Zn}$ level on the rations leads to decreased appetite of animals and thus it was reflected in the amount of fed intake and digestibility coefficients and feeding values, which reflect on the decrease of the available nutrients to the mammary gland and 
consequently decreased of milk production (Page et al., 2020). Concerning, the suckling milk composition for percentages of fat, protein, lactose and SMEV $(\mathrm{kcal} / \mathrm{kg}$ ) in maternal goats fed different rations during suckling periods are displayed in Table (5). Fat percentage at $5^{\text {th }}$ days of post-partum was markedly higher than that the following days over all experimental rations. Milk fat percentage was significant higher $(\mathrm{P}<0.05)$ in goats fed $\mathrm{T} 3$ and $\mathrm{T} 2$ than those fed the control one (T1). These results are a good agreement with those obtained by Bakour et al., (2017). According to findings of Khalifa et al. (2013), colostrum up to 5 days post-partum contained substantially less stearic and oleic acids and more myristic and palmitic acids than the normal milk fat thus, the mixture of colostrum from 3, 4, or $5 \mathrm{~d}$. might change the normal fat distribution in suckling milk. While, milk protein percentage, (Table 5) cleared that tested rations $\mathrm{T} 3$ and $\mathrm{T} 2$ were recorded significant higher $(\mathrm{P}<0.05)$ compared with control one, being no significant differences were observed among T3 and T2 treatments. Also protein percentage was higher after $5^{\text {th }}$ days than that with other following suckling periods up to weaning time $(90 \mathrm{~d}$.) over all dietary treatments. Generally, results in other breeds showed a similar decrease in total protein content up to weaning as recorded by Chen et al. (2019). Similarly, milk lactose content was significant higher for two tested rations (T2 and T3) than that of control (T1) over all suckling period. Increasing suckling milk lactose percentage for $\mathrm{T} 3$ or $\mathrm{T} 2$ rations could be related to more content of carbohydrates in bee bread extract $(47.40 \%)$ as has been described previously by Bakour $\boldsymbol{e t}$ al. (2017). With advanced of suckling phases lactose concentration was increased over all treatments up to weaning time. In this context, Emrobowansan et al., (2017) found that lactose production causes water influx in milk through osmotic effects and its value was observed to be lower in colostrum than in mature milk in goats breed. Also data of Table (5) showed that animals fed T3 or T2 were recorded higher suckling milk energy than that with animals fed $\mathrm{T} 1$ over the different suckling periods, however, the differences were not significant among them over all suckling periods. The suckling milk energy is relied on both fat and protein concentrations in suckling milk, thus there was an increase in fat and protein levels in suckling milk maternal goats fed $\mathrm{T} 3$ or $\mathrm{T} 2$ than those animals fed $\mathrm{T} 1$ rations. In General, the improvement in nutritional status, could be reflect positive effect on increasing suckling milk constituents of from fat , protein percentages and suckling milk energy (Abdel-Gawad et al., 2017). 


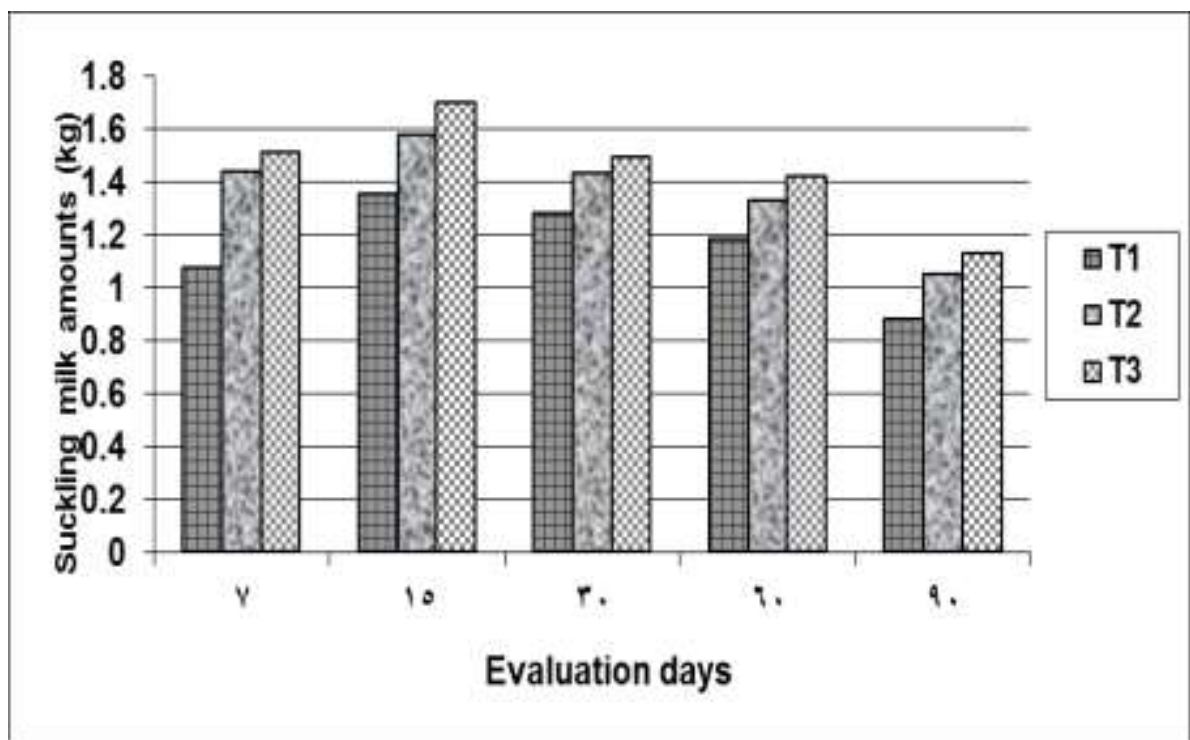

Fig. 1: Average daily milk yield of maternal goats fed different experimental rations during suckling periods.

Table (5): Composition of milk goats fed the experimental rations during suckling periods.

\begin{tabular}{|c|c|c|c|c|c|}
\hline \multirow[t]{2}{*}{ Specification } & \multirow{2}{*}{$\begin{array}{c}\text { Suckling } \\
\text { phases }\end{array}$} & \multirow{2}{*}{$\begin{array}{c}\text { Evaluation } \\
\text { days }\end{array}$} & \multicolumn{3}{|c|}{ Experimental treatments } \\
\hline & & & T1 & $\mathrm{T} 2$ & T3 \\
\hline \multirow{5}{*}{ Fat ,\% } & \multirow{3}{*}{ Early } & 5 & $6.13 \pm 0.16^{b}$ & $6.78 \pm 0.11^{\mathrm{a}}$ & $6.82 \pm 0.13^{a}$ \\
\hline & & 15 & $4.17 \pm 0.11^{b}$ & $4.75 \pm 0.09^{a}$ & $4.76 \pm 0.13^{a}$ \\
\hline & & 30 & $3.58 \pm 0.08^{b}$ & $3.80 \pm 0.03^{a}$ & $3.92 \pm 0.07^{a}$ \\
\hline & Middle & 60 & $4.22 \pm 0.05^{b}$ & $4.50 \pm 0.04^{\mathrm{a}}$ & $4.61 \pm 0.08^{a}$ \\
\hline & Late & 90 & $4.28 \pm 0.06^{b}$ & $4.56 \pm 0.05^{a}$ & $4.68 \pm 0.07^{a}$ \\
\hline \multirow{5}{*}{ Protein, \% } & \multirow{3}{*}{ Early } & 5 & $4.63 \pm 0.04^{b}$ & $4.87 \pm 0.05^{a}$ & $4.95 \pm 0.06^{a}$ \\
\hline & & 15 & $3.33 \pm 0.06^{b}$ & $3.65 \pm 0.07^{a}$ & $3.67 \pm 0.07^{a}$ \\
\hline & & 30 & $3.20 \pm 0.04^{b}$ & $3.47 \pm 0.03^{a}$ & $3.52 \pm 0.03^{a}$ \\
\hline & Middle & 60 & $3.30 \pm 0.04^{b}$ & $3.65 \pm 0.12^{a}$ & $3.73 \pm 0.14^{a}$ \\
\hline & Late & 90 & $3.21 \pm 0.03^{b}$ & $3.52 \pm 0.11^{a}$ & $3.53 \pm 0.13^{a}$ \\
\hline \multirow{5}{*}{ Lactose, \% } & \multirow{3}{*}{ Early } & 5 & $4.38 \pm 0.03^{b}$ & $4.68 \pm 0.06^{a}$ & $4.70 \pm 0.09^{a}$ \\
\hline & & 15 & $5.05 \pm 0.05^{b}$ & $5.55 \pm 0.04^{a}$ & $5.63 \pm 0.04^{a}$ \\
\hline & & 30 & $5.30 \pm 0.04^{b}$ & $5.62 \pm 0.05^{a}$ & $5.72 \pm 0.05^{a}$ \\
\hline & Middle & 60 & $5.33 \pm 0.03^{b}$ & $5.65 \pm 0.04^{a}$ & $5.77 \pm 0.08^{a}$ \\
\hline & Late & 90 & $5.23 \pm 0.05^{b}$ & $5.57 \pm 0.04^{\mathrm{a}}$ & $5.58 \pm 0.05^{a}$ \\
\hline \multirow{5}{*}{$\begin{array}{l}{ }^{*} \text { SMEV } \\
\text { (kcal/kg) }\end{array}$} & \multirow{3}{*}{ Early } & 5 & $284.22 \pm 1.43$ & $291.14 \pm 0.81$ & $291.92 \pm 1.01$ \\
\hline & & 15 & $259.60 \pm 1.14$ & $266.61 \pm 0.95$ & $266.86 \pm 1.13$ \\
\hline & & 30 & $253.89 \pm 0.85$ & $257.73 \pm 0.27$ & $258.66 \pm 0.61$ \\
\hline & Middle & 60 & $259.10 \pm 0.45$ & $264.92 \pm 0.58$ & $266.16 \pm 1.11$ \\
\hline & Late & 90 & $258.91 \pm 0.49$ & $264.51 \pm 0.36$ & $265.95 \pm 0.38$ \\
\hline
\end{tabular}

a,b,c means in the same row direction with different superscripts are significantly different (P<0.05).

* SMEV: suckling milk energy. 
Feed intake and feed conversion:

Intakes of experimental ration ingredients as well as the intake as TDN and DCP are presented in Table (6). Data cleared that there were no significant differences among the experimental dietary treatments regarding the rations ingredients (CFM, BH and $\mathrm{RS}$ ) and feed intake as DM, TDN and $\mathrm{CP}$ values. However the animals fed T3 recorded the higher value of DCPI, followed by $\mathrm{T} 2$, while the lowest one was recorded for $\mathrm{T} 1$ ration, being such differences were not significant $(\mathrm{P}<0.05)$. This might be due to the increase in protein digestibility that attributed to more nutritional status rich in vitamins, minerals, antioxidants, and healthy fats, within bee bread ( as the feed additives), which located in either T2 or T3 treatments compared to the low nutritional status without bee bread in T1, (Roulston and Cane 2000).

Table (6): Feed intake of goats fed different experimental rations.

\begin{tabular}{|c|c|c|c|}
\hline \multirow[b]{2}{*}{ Item } & \multicolumn{3}{|c|}{ Experimental treatments } \\
\hline & T1 & T2 & T3 \\
\hline BBE extract & - & 2.5 & 5.0 \\
\hline \multicolumn{4}{|c|}{ Feed intake as DM basis $(\mathrm{kg} / \mathrm{h} / \mathrm{d})$} \\
\hline CFM & 0.879 & 0.879 & 0.879 \\
\hline BH & 0.314 & 0.314 & 0.314 \\
\hline $\mathbf{R S}$ & 0.062 & 0.062 & 0.062 \\
\hline \multicolumn{4}{|c|}{ Total feed intake $(\mathrm{kg} / \mathrm{h} / \mathrm{d})$} \\
\hline DM & 1.255 & 1.255 & 1.255 \\
\hline TDN & 0.760 & 0.760 & 0.760 \\
\hline DCP & 0.11 & 0.113 & 0.115 \\
\hline \multicolumn{4}{|l|}{ Feed conversion } \\
\hline DM, kg/ kg milk & $1.089^{\mathrm{a}}$ & $0.916^{b}$ & $0,866^{\mathrm{c}}$ \\
\hline TDN, kg/ kg milk & $0.66^{\mathrm{a}}$ & $\mathbf{0 , 5 4 7}{ }^{\mathrm{b}}$ & $0.524 b$ \\
\hline DCP, kg/ kg milk & $\mathbf{0 . 9 5 5}^{\mathrm{a}}$ & $0.825^{b}$ & $\mathbf{0 . 7 9 3}^{\mathrm{b}}$ \\
\hline
\end{tabular}

a,b,c means in the same row direction with different superscripts are significantly different $(\mathbf{P}<\mathbf{0 . 0 5})$.

Concerning, the feed conversion expressed as the amount intake of DM, TDN or DCP to give one $\mathrm{kg}$ milk (Table 6) showed that the animals fed $\mathrm{T} 3$ and those fed T2 appeared better feed conversion $(\mathrm{P}<0.05)$ compared with animals fed T1 (control ration), however, significant differences were not found with animals fed T3 and those fed T2. Improved feed conversion for animals fed $\mathrm{T} 3$ or $\mathrm{T} 2$ rations might be attributed mainly to the higher milk yield and nutrients digestibility. Currently results is cleared that bee bread is a lactogenic substance, because it can increase milk production by scavenging activity of free radical (Bakour $\boldsymbol{e t}$ al., 2017), supplied goats with vitamins (Mărgăoan et al., 2019), antioxidant (Bleha et al., 2019), goodness energy and fatty acids (Dranca $\boldsymbol{e t}$ al., 2020) and organic acids (Mohammad et al., 2020). 


\section{Immunoglobulin concentrations in suckling milk}

Immunoglobulin IgG, IgA, and IgM concentrations as affected by dietary treatments during 90 days of suckling period are showed in Table (7). The highest values of $\mathrm{IgG}$, IgA and $\operatorname{IgM}$ concentrations were recorded at early suckling period at 5,15 and 30 days and then decreased $(\mathrm{P}<0.05)$ gradually at in middle and late suckling period at 60 and 90 day, over all different experimental rations. Also, tested rations $\mathrm{T} 3$ or $\mathrm{T} 2$ were led to a significant $(\mathrm{P}<0.05)$ higher concentrations in $\operatorname{IgG}, \operatorname{IgA}$ and $\mathrm{IgM}$ than those recorded with $\mathrm{T} 1$ during different suckling periods. The obtained values of IgG, IgA, and IgM in the present study are within the normal range that reported by (Kocina et al., 2012) who estimated its concentrations up to $4.3,4.95$ and $6.17 \mathrm{mg} / \mathrm{mL}$, respectively, when udder was diagnosed acute inflammation. The immunoglobulins have an important role in immunological defense response of the udder and also concentrations of all classes of immunoglobulins were decreased in middle and late suckling periods, but it increases during the udder inflammation (Zuluaga et al., 2015). In this context, Kieliszek et al., (2018) indicated that bee bread played a major role to activate the production of hormones which are increase the number of receptors of secretory epithelial cells in mammary tissue which are considered on indirect way to synthesis $\operatorname{IgG}, \operatorname{IgA}$ and $\operatorname{IgM}$. No studies have been found relative to the repercussions of the $\operatorname{IgG}, \operatorname{IgA}$ and IgM content on the milk characteristics when goats received bee bread extract. Generally, the best concentrations of $\operatorname{IgG}, \operatorname{IgA}$ and $\operatorname{IgM}$ in $\mathrm{T} 3$ or T2 might be related to the most role of micro and macro-elements and vitamins (Mărgăoan et al., 2019) and antioxidants (Bleha et al., 2019) that potentially improved the immunity system which reflects on milk production, positively.

Table (7): Mean of IgG, IgA and IgM for lactating goats fed experimental rations during different suckling periods.

\begin{tabular}{|c|c|c|c|c|c|}
\hline \multirow[t]{2}{*}{ Specification } & \multirow{2}{*}{$\begin{array}{c}\text { Suckling } \\
\text { phases }\end{array}$} & \multirow{2}{*}{$\begin{array}{c}\text { Evaluation } \\
\text { days }\end{array}$} & \multicolumn{3}{|c|}{ Experimental treatments } \\
\hline & & & T1 & T2 & T3 \\
\hline \multirow{5}{*}{$\begin{array}{c}\text { IgG, } \\
\text { mg/mL }\end{array}$} & \multirow{3}{*}{ Early } & 5 & $1.72 \pm 0.02^{b}$ & $1.97 \pm 0.02^{\mathrm{a}}$ & $2.14 \pm 0.10^{a}$ \\
\hline & & 15 & $1.07 \pm 0.08^{b}$ & $1.27 \pm 0.09^{\mathrm{a}}$ & $1.32 \pm 0.10^{\mathrm{a}}$ \\
\hline & & 30 & $1.11 \pm 0.02^{b}$ & $1.23 \pm 0.08^{\mathrm{a}}$ & $1.25 \pm 0.07^{\mathrm{a}}$ \\
\hline & Middle & 60 & $0.80 \pm 0.04^{b}$ & $1.16 \pm 0.06^{a}$ & $1.18 \pm 0.05^{a}$ \\
\hline & Late & 90 & $0.71 \pm 0.02^{b}$ & $1.09 \pm 0.03^{\mathrm{a}}$ & $1.12 \pm 0.05^{\mathrm{a}}$ \\
\hline \multirow{5}{*}{$\begin{array}{c}\text { IgA, } \\
\text { mg/mL }\end{array}$} & \multirow{3}{*}{ Early } & 5 & $0.10 \pm 0.04^{b}$ & $0.17 \pm 0.01^{\mathrm{a}}$ & $0.18 \pm 0.01^{\mathrm{a}}$ \\
\hline & & 15 & $0.12 \pm 0.00^{b}$ & $0.19 \pm 0.01^{\mathrm{a}}$ & $2.0 \pm 0.01^{a}$ \\
\hline & & 30 & $0.14 \pm 0.00^{b}$ & $0.20 \pm 0.01^{\mathrm{a}}$ & $0.22 \pm 0.01^{\mathrm{a}}$ \\
\hline & Middle & 60 & $0.11 \pm 0.01^{b}$ & $0.18 \pm 0.03^{\mathrm{a}}$ & $0.19 \pm 0.02^{a}$ \\
\hline & Late & 90 & $0.07 \pm 0.00^{b}$ & $0.14 \pm 0.01^{a}$ & $0.15 \pm 0.00^{\mathrm{a}}$ \\
\hline \multirow{5}{*}{$\begin{array}{c}\text { IgM } \\
\text { mg/mL }\end{array}$} & \multirow{3}{*}{ Early } & 5 & $0.14 \pm 0.01^{b}$ & $0.51 \pm 0.02^{\mathrm{a}}$ & $0.54 \pm 0.02^{\mathrm{a}}$ \\
\hline & & 15 & $0.28 \pm 0.01^{b}$ & $0.45 \pm 0.01^{\mathrm{a}}$ & $0.49 \pm 0.02^{\mathrm{a}}$ \\
\hline & & 30 & $0.21 \pm 0.01^{b}$ & $0.39 \pm 0.02^{a}$ & $0.43 \pm 0.02^{\mathrm{a}}$ \\
\hline & Middle & 60 & $0.17 \pm 0.01^{b}$ & $0.29 \pm 0.02^{\mathrm{a}}$ & $0.30 \pm 0.00^{\mathrm{a}}$ \\
\hline & Late & 90 & $0.16 \pm 0.00^{b}$ & $0.22 \pm 0.02^{a}$ & $0.24 \pm 0.02^{\mathrm{a}}$ \\
\hline
\end{tabular}

a,b,c means in the same row direction with different superscripts are significantly different $(\mathbf{P}<\mathbf{0 . 0 5})$. 


\section{Growth rate of kids during suckling period}

Results presented in Table (8) shown that kid LBW and MW in the T3 and $\mathrm{T} 2$ tested rations were significantly higher $(\mathrm{P}<0.05)$ than those of $\mathrm{T} 1$ control one over all suckling months of the experiment. There were no significant differences $(\mathrm{P}>0.05)$ in these two measures between $\mathrm{T} 3$ and $\mathrm{T} 2$ over the whole suckling period. Also, the daily gain of T3 and T2 rations appeared higher $(\mathrm{P}<0.05)$ values than that of control one $\mathrm{T} 1$ at periods $1-30$, 30-90 and 60-90 days as shown in Table (8). The provision of immunoglobulins (IgG, IgA and IgM) concentration in both T3 and T2 groups of kids appears to explain the more body weight and weight gain of kids in both tested groups than that of control one. Therefore, Yaakub (2011) found that kids with adequate serum $\operatorname{IgG}, \operatorname{IgA}$, and $\operatorname{IgM}$ were better able to suppressing pathogenic invasions, mounting a rapid immune response for defense. Also, the same authors indicated that $\mathrm{IgG}, \operatorname{IgA}$ and IgM were associated with improving normal growth with an increased daily live weight gain. The best suckling milk components (as fat, protein, and lactose) in T3 and T2 goat groups had a heavier body weight of kids than those in $\mathrm{T} 1$ group. In harmony with the present results Atay (2016) noticed that there were high correlations $(\mathrm{P}<0.01)$ between live body weight and milk composition. In perspectives, it is safe to conclude that the addition of BBE into the diets of kids (T2 and T3) didn't have any negative effect on palatability of feed intake that may be related to the best of suckling milk energy (kcal/kg) compared to control kids in (T1) as illustrated in table 5 . Results presented in this study were similar to those reported by AbdelGawad et al. (2017) who found the energy suckling milk at 90 days of suckling was 251.35, 264.48, and $266.45 \mathrm{kcal} / \mathrm{kg}$ where they in corresponding could be attained kid growth rates up to $6.93,7.83$ and 7.95 $\mathrm{kg}$. As well, Bonos et al. (2017) suggested that the best nutritional condition during kid life potentially has considerable effects on growth rate and reproductive performance. Moreover, the amount of suckling milk yield may be played an important role in the growth rate of kids. Therefore, T3 and T2 dietary treatments could achieve higher suckling milk yields than that of control one (T1). In this regard, Abdel-Gawad and Desoky (2018) noticed that when daily suckling milk amounts were 1.61 and $1.76 \mathrm{~kg} / \mathrm{h}$ the weaning body weight of kids were 10.03 and $10.12 \mathrm{~kg}$ for Zaraibi goat, respectively. Generally, the present study has shown that supplying BBE to goats during suckling months might be able to supply adequate energy, protein, minerals, vitamins, and antioxidant materials which could optimize of metabolic processes and kid growth rates (Chen et al., 2019). 
Table (8): LBW, metabolic weight, and daily gain of kids during suckling period.

\begin{tabular}{|c|c|c|c|}
\hline \multirow[t]{2}{*}{ Specification } & \multicolumn{3}{|c|}{ Experimental treatments } \\
\hline & T1 & $\mathbf{T 2}$ & T3 \\
\hline Body weight of kid (kg) at birth & $1.91 \pm 0.07$ & $2.04 \pm 0.04$ & $2.21 \pm 0.07$ \\
\hline 30 days & $5.00 \pm 0.43^{b}$ & $7.33 \pm 0.14^{\mathrm{a}}$ & $8.25 \pm 0.33^{\mathrm{a}}$ \\
\hline 60 days & $5.58 \pm 1.00^{b}$ & $9.25 \pm 0.28^{\mathrm{a}}$ & $9.95 \pm 0.42^{\mathrm{a}}$ \\
\hline 90 days & $6.67 \pm 1.21^{b}$ & $10.67 \pm 0.31^{\mathrm{a}}$ & $11.58 \pm 0.49^{\mathrm{a}}$ \\
\hline Metabolic weight & $4.42 \pm 0.78^{b}$ & $6.73 \pm 0.13^{\mathrm{a}}$ & $7.00 \pm 0.20^{\mathrm{a}}$ \\
\hline \multicolumn{4}{|l|}{ Daily gain $(\mathrm{g} / \mathrm{d})$} \\
\hline 1-30 days & $113.50 \pm 14.62^{b}$ & $182.47 \pm 53.93^{a}$ & $211.20 \pm 12.40^{\mathrm{a}}$ \\
\hline 1-60 days & $65.68 \pm 29.44^{b}$ & $122.17 \pm 11.20^{\mathrm{a}}$ & $130.64 \pm 11.47$ \\
\hline $1-90$ days & $55.71 \pm 13.22^{b}$ & $97.85 \pm 32.77^{\mathrm{a}}$ & $105.33 \pm 55.81^{\mathrm{a}}$ \\
\hline 30-60 days & $49.44 \pm 14.05^{b}$ & $52.78 . \pm 9.59^{a}$ & $63.89 \pm 7.63^{\mathrm{a}}$ \\
\hline 30-90 days & $55.56 \pm 19.96^{b}$ & $108.33 \pm 2.29^{a}$ & $113.89 \pm 9.25^{\mathrm{a}}$ \\
\hline 60-90 days & $36.11 \pm 15.05^{b}$ & $50.00 \pm 5.03^{\mathrm{a}}$ & $55.56 \pm 11.11^{\mathrm{a}}$ \\
\hline
\end{tabular}

a,b,c means in the same row direction with different superscripts are significantly different $(\mathbf{P}<0.05)$. Metabolic weight $(\mathrm{MW})=($ initial body weight $(\mathrm{kg})+$ final body weight $(\mathrm{kg}) \div 2)^{0.75}$, (Willems et al. 2013).

\section{Biochemical constituents of blood of goats}

Additional of BBE up to 2.5 or $5.0 \mathrm{ml} / \mathrm{h}$ had significant increased $(\mathrm{P}<0.05)$ the concentrates of plasma glucose, total protein, globulin and $\mathrm{HDL}$, while significant decreased $(\mathrm{P}<0.05)$ the concentrates of serum albumin, cholesterol, LDL, triglyceride, AST, ALT, and creatinine (Table 9). Non-significant $(\mathrm{P}>0.05)$ differences observed between the dosages 2.5 or $5.0 \mathrm{ml}$ of BBE / h. Exclusively, bee bread additives had positive effect on nanny goats blood metabolic performance due to the presence a lot of vital substances (as antioxidants, vitamins, mineral, essential fatty acids, etc.) which are able to improve nutritive value of feed as well as feed digestibility and absorption (Barene et al., 2015). In fact, bee bread is rich in carbohydrates which represent up to (55\%) in which it included (from 8.2 to 13.1 ) as glucose and around $19.9 \%$ fructose and (from 15.8 to 18.4\%) sucrose according to Ismail $\boldsymbol{e t}$ al., (2018). The increases in serum total protein and globulin may be due to the highest percentage of protein (47.40\%) in bee bread (Bakour et al., 2017). On the other hand, Attia et al. (2011) reported that bee pollen (as a portion of bee bread) could be improved serum protein $(7.00 \mathrm{~g} / \mathrm{dl})$, serum glucose $(124.20 \mathrm{mg} / \mathrm{dl})$ and serum globulin $(3.04 \mathrm{~g} / \mathrm{dl})$ in rabbits received bee pollen at $200 \mathrm{mg} / \mathrm{kg}$ of BW correspondingly to $5.06 \mathrm{~g} / \mathrm{dl}, 94.30 \mathrm{mg} / \mathrm{dl}$ and $2.42 \mathrm{~g} / \mathrm{dl}$ in rabbits that received diet free from bee pollen (control). Inversely, the current study showed that albumin significantly lower in T3 and T2 than that in T1. These results are in harmony those obtained by with Ghorbel $\boldsymbol{e t}$ al., (2015) who found that bee bread might lobe decreased the value albumin concentration. Furthermore, Sharma et al., (2016) reported that the most 
albumin exposure could be caused oxidative stress (OS) and inflammation and decreased the activities of the antioxidant enzymes such as superoxide dismutase, catalase, and glutathione peroxidase. The decreases in serum lipids and cholesterol could be due to phospholipids and PUFA particularly linolenic fatty acid which represented at $2.31 \%$ in bee bread extract (Bakour et al., 2017). Regarding the liver functions, our studies showed that honey, part of bee bread could cause amelioration of positive action on liver enzymes, (Bakour et al., 2017) who reported that the preventive effect against liver injury might be due to honey effect and probably bee pollen. Also, Sharma et al. (2016) found that the use of bee honey as antioxidants could be ameliorate liver enzymes. Regarding, the mechanism of this action, Bakour et al., (2017) noticed that the antioxidant properties of honey and bee pollen might play a role in their favorable effect on kidney function by decreased CI4 which causes cellular damage in some organs, mostly in the liver, kidneys, and lungs.

Table (9): Biochemical constituents of blood in goats during suckling periods.

\begin{tabular}{|c|c|c|c|}
\hline \multirow[t]{2}{*}{ Specification } & \multicolumn{3}{|c|}{ Experimental treatments } \\
\hline & T1 & T2 & T3 \\
\hline Glucose, mg/dl & $100.20 \pm 0.97^{b}$ & $113.60 \pm 0.60^{a}$ & $113.80 \pm 0.37^{\mathrm{a}}$ \\
\hline Total protein, g/dl & $5.50 \pm 0.10$ & $6.34 \pm 0.22^{\mathrm{a}}$ & $6.38 \pm 0.18^{\mathrm{a}}$ \\
\hline Albumin, g/dl & $3.08 \pm 0.16^{a}$ & $2.50 \pm 0.04^{b}$ & $2.46 \pm 0.17^{b}$ \\
\hline Globulin, g/dl & $2.76 \pm 0.05^{b}$ & $3.52 \pm 0.16^{\mathrm{a}}$ & $3.56 \pm 0.18^{\mathrm{a}}$ \\
\hline Total lipids, mg/dl & $490.20 \pm 2.04^{\mathrm{a}}$ & $472.80 \pm 4.17^{b}$ & $471.80 \pm 4.57^{b}$ \\
\hline Cholesterol, mg/dl & $158.46 \pm 0.40^{\mathrm{a}}$ & $144.20 \pm 1.01^{b}$ & $143.14 \pm 0.47^{b}$ \\
\hline HDL, mg/dl & $95.72 \pm 1.28^{b}$ & $113.28 \pm 0.73^{a}$ & $114.14 \pm 0.43^{\mathrm{a}}$ \\
\hline LDL, mg/dl & $188.88 \pm 0.55^{a}$ & $153.08 \pm 0.52^{b}$ & $154.84 \pm 1.36^{b}$ \\
\hline Triglyceride, mg/dl & $587.56 \pm 1.32^{a}$ & $417.58 \pm 1.43^{b}$ & $416.64 \pm 1.34^{b}$ \\
\hline AST, U/dl & $30.18 \pm 0.39^{\mathrm{a}}$ & $26.62 \pm 0.35^{b}$ & $25.74 \pm 0.56^{b}$ \\
\hline ALT, U/dl & $20.94 \pm 0.52^{a}$ & $16.02 \pm 0.17^{b}$ & $15.16 \pm 0.17^{b}$ \\
\hline Creatinine, mg/dl & $133.40 \pm 0.51^{a}$ & $131.40 \pm 0.68^{b}$ & $130.60 \pm 0.58^{b}$ \\
\hline
\end{tabular}

Means within the same row direction with different superscripts are significantly different $(\mathbf{P}<\mathbf{0 . 0 5})$.

\section{Economic efficiency}

Results of economic efficiency in Table (10) obtained that total feed cost tended to increase with increasing the dose of BBE supplementation. However, the animals fed $\mathrm{T} 3$ and those fed $\mathrm{T} 2$ appeared better milk yield and composition, which reflects on growth rate of kids during suckling period and return 2.43 and $2.48 \mathrm{LE}$, respectively, compared with animals, fed T1. Moreover, economic efficiency improved by 3.6 and $7.2 \%$ with $\mathrm{T} 3$ and $\mathrm{T} 2$, respectively as compared to control rations. 
Table (10): Economic efficiency of lactating does fed experimental rations.

\begin{tabular}{|l|c|c|c|}
\hline \multirow{2}{*}{ Item } & \multicolumn{3}{|c|}{ Experimental goats } \\
\cline { 2 - 4 } & T1 & T2 & T3 \\
\hline No. of Dams & $\mathbf{6}$ & 6 & $\mathbf{6}$ \\
\hline Experimental periods, days & $\mathbf{9 0}$ & 90 & $\mathbf{9 0}$ \\
\hline Feed cost (LE/d) & & & 1.255 \\
\hline Av, DMI, k;/ h/d & 1.255 & 1.255 & 5.55 \\
\hline Price, LE & 4.55 & 5.05 & 1.45 \\
\hline Av. Milk yield, k;/ h/d & 1.152 & 1.37 & $\mathbf{7 . 9 8}$ \\
\hline Price, Milk yield, k;/ h/d, LE & $\mathbf{6 . 3 4}$ & $\mathbf{7 . 5 3}$ & $\mathbf{2 . 4 3}$ \\
\hline Return, LE & 1.79 & 2.48 & $\mathbf{1 . 4 4}$ \\
\hline Economic efficiency & 1.39 & 1.49 & +103.6 \\
\hline $\begin{array}{l}\text { The economic efficiency } \\
\text { improvement } \%\end{array}$ & - & +107.2 & \\
\hline
\end{tabular}

The price of feedstuffs and products: $\mathrm{FCM} / \mathrm{Ton}=4500 \mathrm{LE}$; $\mathrm{BH} / \mathrm{Ton}=1800 \mathrm{LE}$; $\mathrm{RS} / \mathrm{Ton}=500 \mathrm{LE} ; \mathrm{BBE} / \mathrm{g}=2 \mathrm{LE} ; \mathrm{Milk} / \mathrm{kg}=5.5 \mathrm{LE}$ and $\mathrm{LBW}$ gain/ $\mathrm{kg}=120 \mathrm{LE}$; economic efficiency $=$ Price, Milk yield $/$ feed cost

\section{CONCLUSION}

Based on the finding of this study, bee bread extract is considering one of the most valuable feed additives for goats at suckling period, due to its highly contents of carbohydrate, protein, minerals, vitamins and fatty acids which enhancing natural antioxidants functionality. Thus, it had beneficial effect on suckling milk yield, its composition, immunoglobulins and blood metabolic, which leading to the goodness productive kids' lifespan. As well, it could be play an important role for improved of digestion coefficients, feeding values, fed conversion ratio and economic efficiency, which reflects on productive performance of goats during suckling periods.

\section{REFERENCES}

Abdel-Gawad, A. M. and A. L. I. Desoky (2018). Suckling milk yield of Zaraibi goats as affected by measuring methods. Journal Animal and Poultry Production, Mansoura University, 9 (3): 157- 162.

Abdel-Gawad, A.M. ; H.R. Behery ; G.I. El-Emam ; T.H. El-Sawah ; W.M. Sadek and E.I. Khalifa (2017). Effect of refused sesame seeds for manufacturing supplement on reproductive and productive performance of dairy goats. Egyptian Journal of Sheep \& Goat Sciences, 12 (3): 119-135.

Al-Salem, H.S. ; R.S. Bhat ; L. Al-Ayadhi and A. El-Ansary (2016). Therapeutic potency of bee pollen against biochemical autistic features induced through acute and subacute neurotoxicity of orally administered propionic acid. BMC Complementary and Alternative Medicine, 16 (1): 120 -125.

AOAC (2007). Association of Official Analytical Chemists. Official Methods of Analysis. $19^{\text {th }}$ Edition. Washington, DC: AOAC. USA. 
Asama, T. ; T.H. Arima ; T. Gomi ; T. Keishi ; H. Tani and Y. Kimura (2015). Lactobacillus kunkeei YB38 from honeybee products enhances IgA production in healthy adults. Journal of Applied Microbiol. , 119 (3): 818 .

Atay, O. (2016). Fattening performance, carcass and meat quality characteristics of Alpine x Hair Goat (F1), Saanen x Hair goat (F1) and Hair goat kids. Journal Tekirdag Agriculture Faculty, 13:129133.

Attia, Y.A. ; A. Al-Hanoun and F. Bovera (2011). Effect of different levels of bee pollen on performance and blood profile of New Zealand White bucks and growth performance of their offspring during summer and winter months. Journal of Animal Physiology and Animal Nutrition, 95: 17-26.

Bakour, M. ; S.A.W. Noori ; E. Nawa ; I. Hamada ; C.F. Anna ; T. AlWaili and L. Badiaa (2017). Antioxidant activity and protective effect of bee bread (honey and pollen) in aluminum-induced anemia, elevation of inflammatory makers and hepato-renal toxicity. Journal Food Science Technology, 5 4(13):4205-4212.

Barene, I. ; D. Irena and S. Sanita (2015). Investigation of bee bread and development of its dosage forms. Medicinos Teorija ir Praktika, 21 (1):16-22.

Bleha, R. ; T. Shevtsova and V. Kruzik (2019). "Bee breads from Eastern Ukraine: composition, physical properties and biological activities. Czech Journal of Food Sciences, 37 (1):1-12.

Bonos, E. ; A. Kargopoulos ; Z. Basdagianni ; D. Mpantis ; E. Taskopoulou ; B. Tsilofiti and I. Nikolakakis (2017). Dietary sesame seed hulls utilization on lamb performance, lipid oxidation and fatty acids composition of the meat. Animal Husbandry, Dairy and Veterinary Science, 1(1): 1-5.

Chen, D. ; X.Y. Li ; X. Zhao ; Y.S. Qin ; X.X. Zhang ; J. Li ; J.M. Wang and C.F. Wang (2019). Proteomics and microstructure profiling of goat milk protein after homogenization. Journal of Dairy Science, 102(5): 3839-3850.

De-Melo, A.A.M. and L.B. de Almeida-Muradian (2017). Health Benefits and Uses in Medicine of Bee Pollen. In Bee ProductsChemical and Biological Properties; Springer: Cham, Switzerland, pp. 261-276.

Dranca, F. ; U. Florin and O. Mircea (2020). Bee bread: Physicochemical characterization and phenolic content extraction optimization. Foods, 9: 2-14.

Duncan's, D. B. (1955). Multiple Range and Multiple (F-test). Biometrice, 11: $1-42$. 
Emrobowansan, M. I. ; M. Voster and Patrick J. Masika (2017). Yield and milk composition at different stages of lactation from a small herd of Nguni, Boer, and Non-Descript goats raised in an extensive production system. Sustainability, 9:3-12.

Ghorbel, I. ; S. Maktouf ; C. Kallel ; C.S. Ellouze ; T. Boudawara and N. Zeghal (2015). Disruption of erythrocyte antioxidant defense system, hematological parameters, induction of pro-inflammatory cytokines and DNA damage in liver of co-exposed rats to aluminium and acrylamide. Chemistry Biological Interaction, 236:31-40.

Habryka, C. ; M. Kruczek and B. Drygas (2016). Bee products used in apitherapy. World Scientific News, 48: 254-258.

Hudz, N. ; R. Ivanova ; J. Brindza ; O. Grygorieva ; Z. Schubertová and E. Ivanišová (2017).Approaches to the determination of antioxidant activity of extracts from bee bread and safflower leaves and flowers. Potravinarstvo Slovak Journal of Food Sciences, 11 (1): 480-488.

Ismail, W.I.W. ; N.H. Nurul ; N.F.M. Siti ; H.H. Nur and N.F.M.R. Mohd (2018). Physicochemical analysis, antioxidant and anti proliferation activities of honey, propolis and beebread harvested from Stingless bee. The International Fundamentum Sciences Symposium, 440:1-7.

Khalifa, E.I. ; H.R. Behery ; Y.H. Hafez ; A.A. Mahrous ; Amal A. Fayed and Hanan A. M. Hassanien (2013). Supplementing nonconventional energy sources to rations for improving production and reproduction performances of dairy Zaraibi nanny goats. Egyptian Journal of Sheep \& Goat Sciences, 8 (2):69-83.

Khalifa, E.I. ; Hanan A.M. Hassanien ; A. H. Mohamed ; A.M. Hussein ; Azza A. M. Abd-Elaal and Azza M.M. Badr (2016). Influence of addition spirulina platensis algae powder on reproductive and productive performance of dairy Zaraibi goats. Egyptian Journal Nutrition and Feeds, 19 (2):251-265.

Kieliszek, M. ; K. Piwowarek ; A.M. Kot ; S. Blażejak ; A. Chlebowska-Śmigiel and I. Wolska (2018). Pollen and bee bread as new health-oriented products. Trends in Food Science and Technology, 71: 170-180.

Kociṇa, I. ; V. Antāne and I. Lūsis (2012). The Concentration of immunoglobulins $\mathrm{A}, \mathrm{G}$, and $\mathrm{M}$ in cow milk and blood in relation with cow seasonal keeping and pathogens presence in the udder. Proceedings Latvia University Agriculture, 27(322):44-53.

Madras-Majewska, B. ; L. Ochnio and M. Ochnio (2015). Use of bee products in livestock nutrition and therapy. Medycyna Weterynaryjna,71 (2): 94-99. 
Mărgăoan, R. ; S. Mirela ; V. Alina ; T. Erkan ; Y. Banu ; M. CorneaCipcigan ; Maria G. Campos and Dan C. Vodnar (2019). Bee Collected pollen and bee bread: bioactive constituents and health benefits. Antioxidants, 8 (12):568.

Mohammad, S.M. ; N.M. Ab-Rashid and N. Zawawi (2020). Botanical origin and nutritional values of bee bread of Stingless Bee (Heterotrigona itama) from Malaysia. Journal of Food Quality,Pp: $1-12$.

NRC (2007). Nutrient requirements of small ruminants: Sheep, goats, cervids, and new world camelids, National Academies Press, Washington, D.C., U.S.A.

Page, C.M. ; T.W. Murphy ; J.B. Taylor ; A.A.M. Julian ; J.R. Whaley ; K.L. Woodruff ; G.L. Hummel ; C.F. Demarco ; D.M. Laverell ; H.C. Cunningham-Hollinger ; D.C. Rule and W.C. Stewart (2020). Effects of dietary Zn on ewe milk minerals and somatic cell count. Translational Animal Science, 4(1): 17-21.

Ribeiro, L.P.S. ; A.N. ; Medeiros ; F.F.R. Carvalho ; E.S. Pereira ; A. P. Souza ; J.M. Santos Neto ; L. R. Bezerra ; ; S. A. Santos and R. L. Oliveira (2018). Performance and mineral requirements of indigenous Canindé goats. Small Ruminant Research, 169:176-180.

Roulston T.H. and J.H. Cane (2000): Bee products nutritional content and digestibility for animals. Plant. Syst. Evol., 222: 187-209.

Saddick, I.M. and B.M. Ahmed (1991). Effect of feeding caseinsupplemented ration to Ossimi lambs: 1- Changes in body weight and measurements, digestibility, nitrogen balance and wool characteristics. Minufiya J. Agric. Res., 16 (1): 315-336.

SAS (2002). Statistical Analysis Systems (SAS) Institute Inc., 2002. SASSTAT. User.

Sharma, D.R. ; W.Y. Wani ; A. Sunkaria ; R.J. Kandimalla ; R.K. Sharma ; D. Verma ; A. Bal and K.D. Gill (2016). Quercetin attenuates neuronal death against aluminum-induced neurodegeneration in the rat hippocampus. Neuroscience, 324:163-176.

Sprinkle, J.E.; S.D. Baker ; J.A. Church ; J.R. Findlay ; S.M. Graf ; K.S. Jensen ; S.K. Williams ; C.M. Willmore ; J. B. Lamb and D.W. Hansen (2018). Case study: Regional assessment of mineral element concentrations in Idaho forage and range grasses. Prof. Animal. Science, 34: 494-504.

Urcan, A.; L.A. Mărghitaș and D.S. Dezmirean (2017). Chemical composition and biological activities of beebread-review. Bulletin of the University of Agricultural Sciences and Veterinary Medicine Cluj-Napoca. Animal Science \& Biotechnologies, 74 (1):1-9.

Willems, O.W.; S.P. Miller and B.J. Wood (2013). Assessment of residual body weight gain and residual intake and body weight gain as feed 
efficiency traits in the turkey (Meleagris gallopavo). Genetics Selection Evolution, 45 (26): 2 - 8.

Yaakub, S. (2011): Effect of colostrum feeding on the serum immunoglobulin level in Saanen crossbred kids. Malaysian Journal Animal Science, 14:25-29.

Zuluaga, C. M. ; J. M. Serrato and M. C. Quicazan (2015). Chemical, nutritional and bioactive characterization of Colombian bee-bread. Chemical Engineering Transactions, 43: 175-180.

\section{تأثير استخدام مستخلص خبز النحل كإضافات علفية على معامل الهضم والأداء الإنتاجي لأمهات الماعز أثناء فترة الرضاعة. منى احمد السيد فرج1 ، عزة أحمد حسن حلى 2 ، أمل مجاهد محمد النمر 3

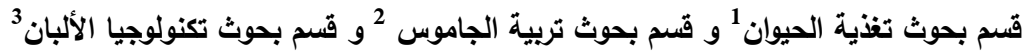

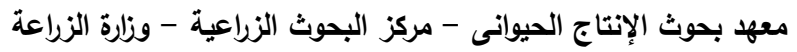

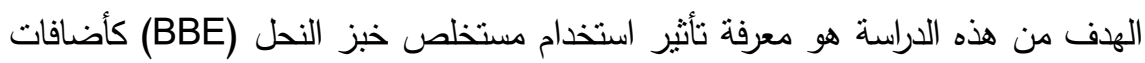

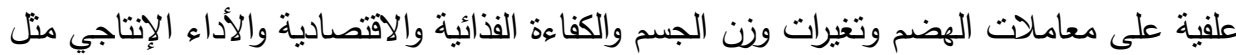

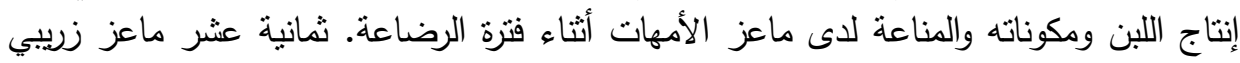

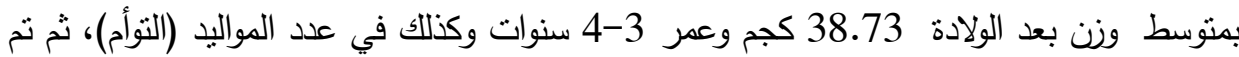

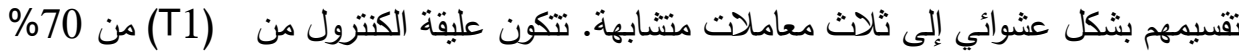

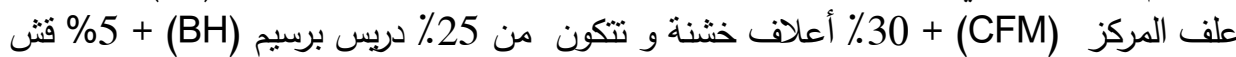
الأرز (RS) وفقًا لمقررات (2007) مRC ، مع 5.0 مل من الماء المقطر / الرأس / يوميًا طوال

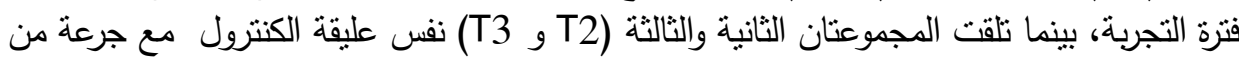

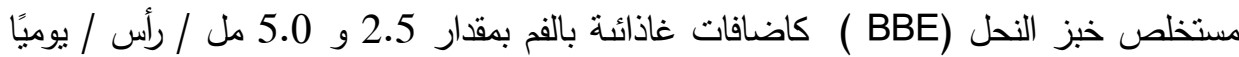

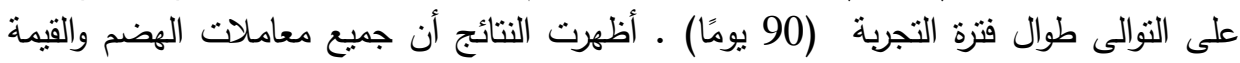

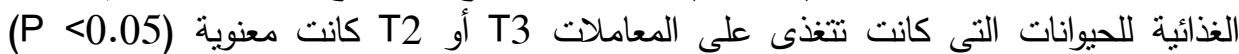

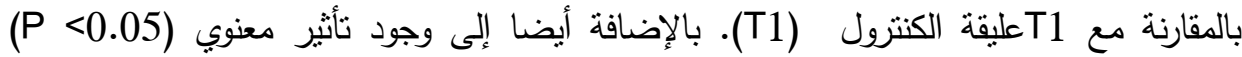

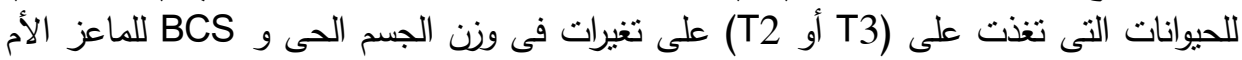

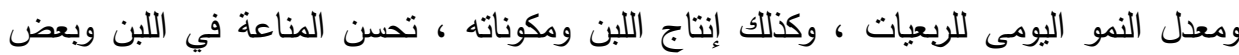

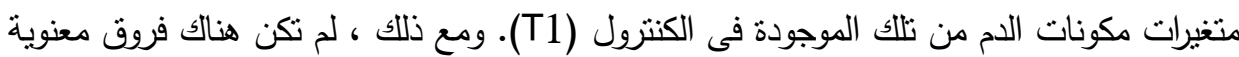

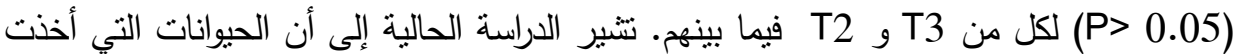

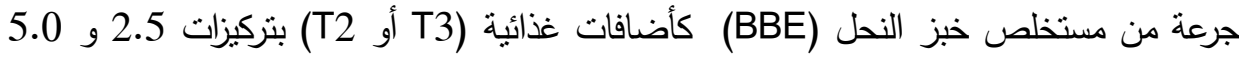

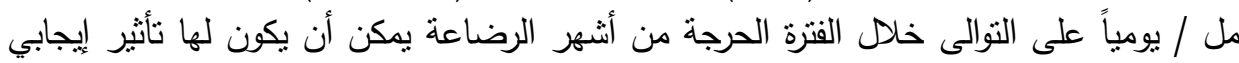

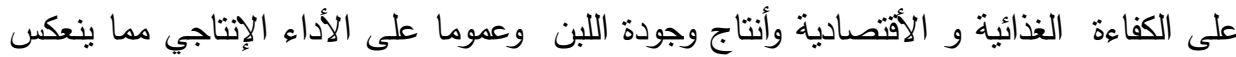
على معدل النمو الصحي للربعيات. 